\title{
Chapter 9. Homo Sapiens is an Evolving Species: Origins of the Austronesians
}

\section{S. W. Serjeantson and X. Gao}

This paper commences with a survey of genetic markers thought to give protection from malaria, in connection with the issue of differentiation between An and NAn populations in Oceania. The closely-linked, highly polymorphic human leukocyte antigen (HLA) class II genes, $H L A-D R$ and $-D Q$, are then examined for evidence of in situ evolution in some Austronesian-speaking populations of Oceania. The authors define the evolutionary forces of founder effect, genetic drift, mutation, migration and selection and look for evidence that these evolutionary forces shaped the genetic profiles seen in contemporary populations of Austronesian speakers. Genetic data confirm an ultimate East Asian origin for Polynesians but also indicate some degree of past gene flow from island Melanesian populations.

\section{Introduction}

Homo sapiens is an evolving species. We make this point because the archaeological debate relating to the development of Lapita pottery in Melanesia has focused on whether it represents an intrusive culture (Spriggs, this volume) or an indigenous development (Allen and White 1989). This debate has been carried over to the question of whether the pre-Polynesians were a colonizing group from Island Southeast Asia, or a group that evolved within Melanesia. The genetic record shows that contemporary Polynesians do indeed share many genetic features with Island Southeast Asians, but they have also undergone further and probably rapid evolution in the past two or three millennia. That is, in the same way that red-slip decoration of early pottery and vessel forms was shared between Island Southeast Asia and Melanesia (Bellwood, this volume), with a local evolution of Lapita decoration in Melanesia (Spriggs, this volume), contemporary Polynesians have ancestral ties with other Mongoloid populations but also have unique genetic features suggesting further evolution.

In the case of Polynesians, much of the evolution appears to have taken place east of Melanesia, in contrast to Lapita decoration, with the population continuously losing genes on the voyage through the Pacific; not many Polynesian genes have been acquired from Melanesians. This was pointed out 30 years ago by the late Roy Simmons of the Commonwealth Serum Laboratories in Melbourne who noted that Eastern Polynesians lacked the B antigen of the ABO blood group system (Simmons 1962). Those early Austronesians who 
remained in Fiji and New Caledonia have evolved also, of course, in the sense that the original genetic repertoire has been overlain by Melanesian genetic elements. Western Melanesians in coastal areas have also evolved through genetic admixture with early Austronesian settlers (Serjeantson et al. 1983).

The debate on the origin of the Polynesians has polarized viewpoints, so that the concept of continuing evolution may have been trivialized inadvertently. This has led to criticisms that the geneticists have been studying the wrong populations. That is, if only geneticists would look at the right contemporary populations the missing links would be found. We doubt this. While agreeing there is a frustrating dearth of genetic information for Island Southeast Asia and for the Lapita homeland area in the Bismarck Archipelago, there is substantial evidence that the evolutionary forces of selection, mutation and genetic drift have resulted in the unique genetic profile seen in contemporary Polynesians. Further, the populations from whom the pre-Polynesians derived were also subject to evolutionary forces, as well as to inward migration by other groups. The missing link may not exist and we may need to accept that if, for example, the nine base-pair deletion in mitochondrial DNA (mtDNA) that is almost universally present in Polynesians (Hertzberg et al. 1989) is found also in 18 per cent of East Asians (Stoneking and Wilson 1989), then that is as good a link as we are likely to get. There is simply not going to be an as-yet-undetected population, somewhere in Island Southeast Asia, where everyone tests positive for the mtDNA deletion and negative for blood group B!

\section{The Impact of Malaria on Human Genetics}

The linguistic dichotomy of populations in Melanesia into Austronesian and non-Austronesian-speaking peoples has tempted some scholars to over-simplify the genetic characteristics of these populations as malaria-resistant and malaria-susceptible, on the basis of gamma-globulin genetics (Clark and Kelly 1993). Kelly (1992) argues that if malaria in Melanesia did indeed have an antiquity greater than about $3600 \mathrm{BP}$, the malarious coastal lowlands would have been open for settlement by Austronesian-speaking immigrants because the non-Austronesian-speakers did not have the genetic capability to live permanently in malarious environments.

The data do not support this scenario. First, it is not clear how malaria could have been sustained without some minimal human population density in the low-lying regions. Second, continuous occupation of a malarious region induces some immunity to malaria among the inhabitants. The sporadic forays of non-Austronesian-speakers into the lowlands, as envisaged by Kelly, are much more likely to be deleterious than continuous occupation. This is evidenced by the finding that in New Guinea, hyperreactive malarious splenomegaly is confined to the Watut people, resident at an altitude of about $1000 \mathrm{~m}$ where malarial transmission is intermittent. 
The third factor to be taken into consideration is the genetic profile of the contemporary population of coastal lowland Melanesia. There are several genetic markers, widespread in non-Austronesian-speaking lowlanders, which are thought to provide some protection against malaria. A description of these genes together with their population distribution is given by Serjeantson et al. (1992) and includes the thalassaemias, glucose-6-phosphate dehydrogenase deficiency, hereditary ovalocytosis and the Gerbich negative blood group. The population distributions of these genes provide some insights into genetic prehistory in Melanesia.

For instance, the gene causing hereditary ovalocytosis, a slight distortion of the red blood cell shape, has a frequency of about 10 per cent throughout lowland Papua New Guinea. The distortion in the red cell membrane arises from a 27 base pair deletion in the DNA encoding Band 3 protein, first shown in a Southeast Asian donor and confirmed as the same gene as that in some Melanesians. The Band 3 defect distorts a number of receptors on the red cell surface and may inhibit malarial invasion. Further evidence that hereditary ovalocytosis provides some protection from high density, lethal parasitemias is provided by epidemiological data and by the apparent absence from the population of people homozygous for the mutant Band 3 gene. That is, despite the apparent lethality of the mutant Band 3 gene when it is inherited from both parents (i.e. a double dose), a high population gene frequency is maintained, presumably through a selective advantage in malarious areas for those with a single dose.

Was this gene introduced to lowland coastal Melanesia, together with malaria, by early Austronesian speakers? The gene's antecedents lie in the Aboriginal populations of Southeast Asia, but it is otherwise rare in contemporary populations of this region. It is found in appreciable frequencies in the Orang Asli populations of Malaysia, has been reported in the Austronesian-speaking Land Dayaks and Iban of Borneo, is prevalent in the hinterland of north and south New Guinea, is absent from New Guinea Highlanders, and is rare in populations east of the New Guinea mainland. This gene thus indicates the likely arrival in Melanesia of a non-Austronesian-speaking wave of immigrants before the early Austronesian-speakers.

The non-Austronesian-speaking Melanesians in malarious areas of New Guinea have other characteristic genetic mutations, such as the Gerbich-negative blood group that is a consequence of a large deletion in the glycophorin $\mathrm{C}$ gene. This mutation may have arisen in one of the populations of the Torricelli Mountains, where it is particularly prevalent, as the gene has a more limited distribution than hereditary ovalocytosis in New Guinea and is not found in the Gulf and Western Provinces. We have detected, using DNA analyses, the glycophorin C gene deletion in low frequency in Micronesia but not in Polynesia. 
Among other genetic markers thought to be related to malaria, the most frequent in non-Austronesian-speaking peoples in lowland New Guinea is a 3.7 $\mathrm{kb}$ deletion in the alpha-globin gene, a mutation that has occurred on an unmistakably Melanesian-area chromosome as attested by the flanking DNA markers. This marker was carried into Polynesia, where it has sporadic occurrence, although it has attained appreciable frequency in New Zealand Maoris, presumably through genetic drift.

\section{Genetic Markers for Austronesians and Non-Austronesians?}

As already noted, the hypothesis that gamma-globulin $(\mathrm{Gm})$ allotypes are associated with differential resistance or susceptibility to malaria is unsupported by any evidence. Is there then a clear dichotomy between non-Austronesian and Austronesian-speaking peoples in lowland New Guinea with Gm and other genetic markers? The answer, as given in detail by Serjeantson et al. (1983), is that there is not. For Gm, as for other genetic markers, geographic distance is a much stronger determinant of genetic affinity than is language, and this is true also for Markham Valley populations where Gm allotypes were originally proposed as sensitive indicators of Austronesian ancestry.

The human leukocyte antigen (HLA) profiles for populations in Melanesia support the notion that there is genetic diversity within non-Austronesian-speaking peoples that must have predated the overlaying of Austronesian elements in some coastal and island non-Austronesian-speaking peoples. A simple test is whether lowland coastal non-Austronesian-speaking people represent a hybrid pool of New Guinea Highlander and Polynesian genes, or whether they have their own separate genetic profile. The HLA-DR system shows that hybridity is not the case. For instance, DRBI*1408 has a frequency of 18 per cent in New Guinea Highlanders but is absent from lowland non-Austronesian-speakers. The latter have some unusual genes, DRBI 1104 and 1602, that are found neither in Highlanders nor Polynesians. The Polynesian gene pool, characterized by high frequencies of DRBI 1201 and 0901 can be drawn from the east Asian but not the Melanesian gene pool.

In a perspective on evolution and population genetics in Papua New Guinea, Serjeantson et al. (1992) showed that populations cluster into four main groups on the basis of ABO blood group and other genetic markers. These are: 1. Austronesian-speaking Melanesians from the New Guinea Islands and Papuan south coast, 2. An and NAn-speaking populations from Madang and Sepik Provinces, 3. speakers of the New Guinea Highlands NAn languages, and 4. non-Austronesian-speakers from New Britain and Papua. The diversity of colonizers in Melanesia is confirmed by the study of mitochondrial DNA, which has shown that at least 18 surviving maternal lineages colonized Papua New Guinea, all deriving from Southeast Asia. 
Austronesian settlements have rarely penetrated the hyperendemic malarial hinterland of New Guinea, but rather, are found on offshore islands and in coastal regions. It seems that early Austronesians may have arrived in Melanesia to find a malarious region inhabited by peoples comparatively well adapted to the environment. For many early Austronesians, it may have been prudent to continue east. It is no coincidence that the majority of Lapita sites are found on small islands.

In the remainder of this paper, we examine the closely-linked, highly polymorphic human leukocyte antigen (HLA) class II genes, HLA-DR and -DQ, for evidence of in situ evolution in some Austronesian-speaking populations of Oceania. We define the evolutionary forces of founder effect, genetic drift, mutation, migration and selection and look for evidence that these evolutionary forces shaped the genetic profiles seen in contemporary populations of Austronesian speakers.

The analyses are based on new data generated by using the polymerase chain reaction (PCR) technique to amplify the HLA-DRB1, DRB3, DRB5, DQA1 and DQBl genes, followed by hybridization with sequence-specific oligonucleotides (SSOs). The PCR-based HLA typing protocol is rapid and sensitive, and looks directly at the gene of interest rather than at flanking regions of DNA as is often the case in restriction fragment length polymorphism (RFLP) analysis. Using the PCR approach, it has been possible to examine many more individuals in many more populations than was possible with traditional serological techniques or RFLP analysis. We have examined more than 2,600 chromosomes from Asia, Oceania and Australia and have identified 82 DR,DQ haplotypes (there are additional haplotypes in Caucasoids); this compares with less than ten DR haplotypes identified in early serological studies (Serjeantson et al. 1982) and with 32 DR,DQ haplotypes detected in RFLP studies (Kohonen-Corish et al. 1988). That is, subtle variation in HLA class II alleles, sometimes a single DNA base change, was not detected in less-sensitive serological and RFLP analyses. In the following, we examine these data for evidence of the impact of evolutionary forces.

\section{Evolutionary Forces: Definitions}

The forces of evolution include founder effects, genetic drift, mutation, migration and selection.

Founder effects. Founder effects arise when the subgroup colonizing previously uninhabited territory is not fully representative, in a genetic sense, of the parental population from which the subgroup derived. Since fission of groups is more likely to occur along family lines than at random (Neel 1968), founder effects may be expected in any colonizing group. The intensity of the founder effect is directly related to the size of the colonizing group — the smaller the number of 
colonizers, the greater the chance that genes from the parental group will be under- or over-represented, or lost altogether.

Genetic drift. Genetic drift occurs when the distribution of genes in a given generation differs from the distribution in the previous generation. This can occur by chance. For instance, all offspring in a given mating may be female, by chance, so that the paternal $\mathrm{Y}$ chromosome is lost to that and future generations, by chance. If all offspring in a given mating are male, the maternal mitochondrial DNA lineage will terminate. The impact of genetic drift is directly related to population size - the smaller the population, the greater the fluctuations in gene frequencies from one generation to the next and the greater the chance that rare or infrequent genes will be lost from the gene pool. The effects of genetic drift can be brought on by catastrophes such as drought, cyclones, epidemics and boating accidents that can dramatically reduce population size, causing in genetic terminology a "bottleneck". If the numbers of males and females in a population are unequal, then the effective population size is closer to the smaller number.

It should be noted that chance can also determine the particular individuals selected for study, so that they may not faithfully represent the larger population from which they are drawn. The smaller the sample size, the greater the chance of sampling effects. Analysis of contemporary populations cannot discriminate readily between founder effects and genetic drift. Bottlenecks may have been more important than founder effects in a population where mtDNA is less diverse than nuclear DNA (Birky et al. 1989).

Mutation. When cells replicate, DNA also replicates and is not always a faithful copy of the original; the error is called a mutation. If the mutation occurs in the germ-line it may be passed to the next generation. Mutations may be a single DNA base substitution, a deletion, a gene duplication and so on. Some mutations, present initially as a single copy in the population, will be lost in genetic drift, but other new mutations will become established in the population, especially if the new mutation has a selective advantage. A point mutation in a functional gene is silent if it occurs in a redundant nucleotide (explained below); otherwise, it results in an amino acid change in a molecule and is then possibly subject to selection.

Selection. Selection operates when a particular gene has a survival advantage, through differential fertility or in survival to reproductive age. Post-reproductive survival differentials are not selected because genes have already been passed to the next generation. Amino acids are encoded by a sequence of three nucleotides called a codon, but the third nucleotide (and sometimes the second) is often redundant. For example, the codons CCA, CCC, CCG and CCT all encode the amino acid residue proline, so that the nucleotide in the third position is redundant. For a given gene, comparison of the rate of nucleotide substitutions 
in the first and third nucleotides of the codon can indicate whether there is positive selection for variability, negative selection for variability, or whether variability is no greater than expected by chance. The extreme polymorphism at the HLA loci has been attributed to selection for diversity per se, due to frequency-dependent selection for high genetic diversity where individuals with a rare allele have some selective advantage, or due to overdominant selection where individuals carrying different alleles at a single locus (i.e. heterozygotes) have a selective advantage. Frequency-dependent and overdominant selection can save rare or new alleles from extinction.

\section{The HLA Data}

$H L A-D R$ and $-D Q$ antigens. The HLA-DR and -DQ human leukocyte class II antigens are encoded by alleles at the closely-linked loci DRA1, DRB1, DQA1 and DQB1. The DRAl locus is not polymorphic, but the WHO nomenclature committee (Bodmer et al. 1991) recognizes 47 alleles at DRB1, eight at DQA1 and 15 at DQB1. Chromosomes carrying DR2 alleles at the DRB1 locus have a second functional locus, DRB5, while some other chromosomes have an alternative second functional locus, DRB3. Not all DR and DQ alleles are found in all populations.

The DR and DQ loci are so closely linked on chromosome six that there are no confirmed reports of a recombination between DRB1 and DQB1, although the occasional recombinational event must have occurred in human evolutionary history to give rise to observed distributions of DR, DQ haplotypes in contemporary populations. For instance, the DR2 allele DRB1*1502 is invariably linked with DRB5*0102 in Caucasoids. However, a unique haplotype DRB1*1502, DRB50101 occurs commonly in Australian Aborigines, Papua New Guinea Highlanders, and in coastal and island Melanesians. This haplotype occurs sporadically in Javanese and Polynesians but not in northern or southern Chinese (Gao and Serjeantson 1991a). This is only one example of how DR,DQ haplotypes can be powerful indicators of population affinities. Further, the number of DR,DQ haplotypes in a given population tends to reflect historic events. A small number of haplotypes indicates founder effects and bottle-necks in population size, and genetic isolation, while a large number of haplotypes can be indicative of historic mixing of populations.

Evidence from HLA studies for founder effects and genetic drift. In a study of DR2-related DR,DQ haplotypes in Asia, Oceania and Australia we identified 15 DRB1, DRB5, DQA1, DQB1 haplotypes (Gao and Serjeantson 1991a). The most diversity was seen in southern Chinese, with nine distinct DR2-related haplotypes, reflecting a great ancestral mixing of populations. The least diversity was seen in Polynesians, with sporadic occurrence of only two DR2-related haplotypes. A similar distribution of haplotype diversity was seen with respect 
to DR4-related haplotypes (Gao and Serjeantson 1991b). A total of 12 DR,DQ combinations was observed in Asia, Oceania and Australia. Ten of these haplotypes were seen in Chinese, but only two were represented in Papua New Guinean Highlanders and a different two in Micronesians. DR4-related haplotypes were not detected in Javanese. While some haplotypes are lost in genetic drift, others can become well-established.

Table 1. The most common HLA-DR,DQ haplotype in each of 19 populations of Asia-Oceania.

\begin{tabular}{|c|c|c|c|c|c|c|}
\hline \multirow[t]{2}{*}{ Population } & \multirow{2}{*}{$\begin{array}{c}\text { Number } \\
\text { tested }^{\mathrm{a}}\end{array}$} & \multicolumn{4}{|c|}{ Most common haplotype ${ }^{b}$} & \multirow{2}{*}{$\begin{array}{l}\text { Frequency } \\
\text { (per cent) }\end{array}$} \\
\hline & & DRB1 & DRB & DQA1 & DQB1 & \\
\hline Kimberley & 149 & AB4 & DRB3"0101 & 0501 & 0402 & 20.7 \\
\hline East Cape York & 148 & 0803 & - & 0103 & 0601 & 29.1 \\
\hline West Cape York & 112 & 0803 & - & 0103 & 0601 & 24.0 \\
\hline PNG Highlands & 114 & 1501 & DRB5 0101 & 0102 & 0602 & 29.8 \\
\hline Madang & 130 & 1101 & DRB3"0202 & 0501 & 0301 & 45.4 \\
\hline New Britain & 120 & 1101 & DRB3 0202 & 0501 & 0301 & 36.7 \\
\hline New Caledonia & 130 & 1101 & DRB3"0202 & 0501 & 0301 & 26.2 \\
\hline Fiji & 114 & 1101 & DRB3 0202 & 0501 & 0301 & 33.3 \\
\hline Western Samoa & 102 & 1201 & DRB3"0101 & 0501 & 0301 & 18.6 \\
\hline Niue & 140 & 1201 & DRB3“0101 & 0501 & 0301 & 30.0 \\
\hline Rarotonga & 156 & $1101^{c}$ & DRB3"0202 & 0501 & 0301 & 20.5 \\
\hline Nauru & 134 & 1202 & DRB3“0301 & 0601 & 0301 & 28.4 \\
\hline Kiribati & 124 & 1202 & DRB3"0301 & 0601 & 0301 & 37.9 \\
\hline Java & 154 & 1202 & DRB3"0301 & 0601 & 0301 & 46.1 \\
\hline Hong Kong & 78 & 0901 & DRB4 & 0301 & 0303 & 14.0 \\
\hline Singapore & 92 & 0901 & DRB4 & 0301 & 0303 & 18.5 \\
\hline Xinjiang & 184 & 07 & DRB4 & 0201 & 0201 & 18.5 \\
\hline Xian & 160 & 0901 & DRB4 & 0301 & 0303 & 14.8 \\
\hline Beijing & 182 & 0901 & DRB4 & 0301 & 0303 & 14.4 \\
\hline
\end{tabular}

${ }^{a}$ No. of haplotypes.

${ }^{\mathrm{b}}$ Haplotype refers to the joint occurrence of the given alleles at the closely-linked DRB1, DRB3 (or DRB4 or DRB5), DQAl and DQB1 loci.

${ }^{\mathrm{C}}$ DRBI*1201 had a frequency of 14.7 per cent.

Table 1 gives the most common DRB1, DRB3 (or DRB4 or DRB5), DQA1 and DQB1 haplotypes found in traditional populations of Asia, Oceania and Australia and their frequencies. In Asia, we have studied Javanese, the Chinese minority population of Xinjiang, northern Chinese from Beijing and Xian, and southern Chinese from Hong Kong and Singapore. Micronesians were from Nauru and Kiribati while Melanesians were from coastal Papua New Guinea (Madang and New Britain), New Caledonia, Fiji and the New Guinea Highlands (Goroka). Polynesians were from Western Samoa, Rarotonga and Niue. Aborigines were from the Kimberley region and from eastern and western Cape York communities.

The most frequent haplotype in Kimberley Aborigines was not seen in any of the other study populations, including Cape York. The most common Cape York haplotype was also found in the Kimberley region Aborigines (18.9 per 
cent) and in Papua New Guinean Highlanders (7.0 per cent). The DRBI 1201 haplotype that predominated in western Polynesians was not seen in other populations, while the DRB1*1202 haplotype in Micronesians and Javanese was otherwise detected only in southern Chinese. Populations less affected by genetic drift, such as those of mainland China, have a more diverse genetic repertoire at HLA-DR so that the frequency of common haplotypes (14-19 per cent) is lower than in Java and Oceania (19-46 per cent). In northern China there were 34 DR,DQ haplotypes but only ten in Nauru, for example.

\section{Evidence from HLA Studies for Mutation}

A new DRB1 allele, a variant of DRw14 called DRB1*1408, has been found in Polynesians (Gao et al. 1992a); this allele equates with 'DRw6P' described in earlier RFLP studies. Among Austronesian speakers tested to date this allele is essentially confined to Polynesians in whom it occurs with moderate frequency (5-7 per cent), but it is absent from Madang, New Britain and Fiji. Four instances of the novel allele have been seen in Melanesians from New Caledonia, but this could represent recent admixture with Polynesians from the Wallis Islands. Closer dissection of the novel Polynesian-specific variant at the DNA level shows that it represents a single nucleotide substitution in an allele still found in contemporary Polynesians, so is almost certainly an example of recent mutation. In Kimberley region Aborigines, three novel HLA-DRBl mutations, not seen elsewhere, account for about 50 per cent of the HLA-DRBl allele frequency (Gao et al. 1992b). 


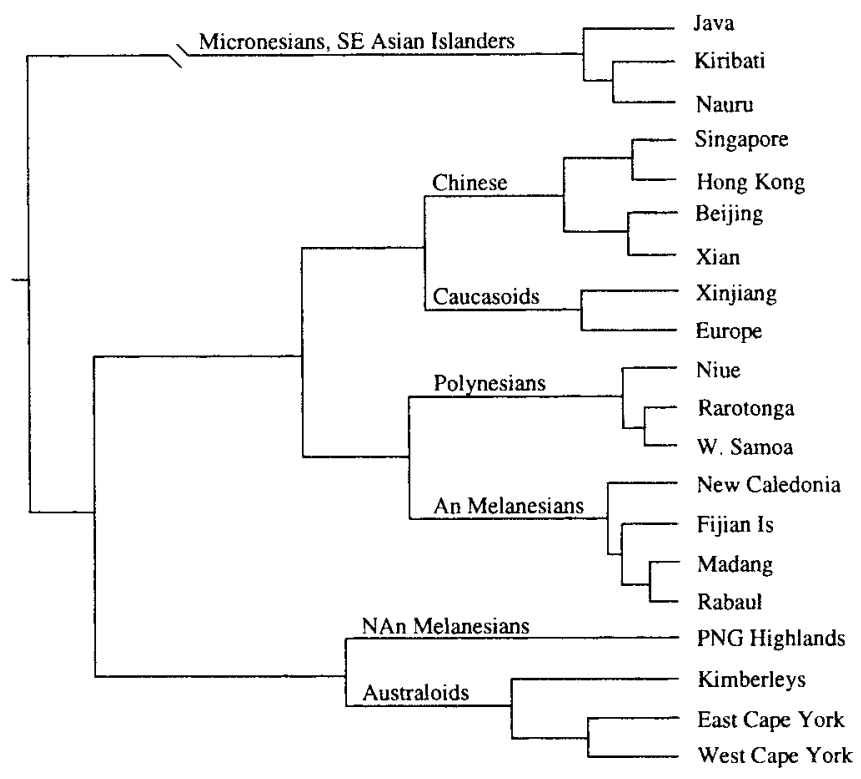

Figure 1. Phylogenetic analysis of the distributions of HLA-DR,DQ haplotypes in 20 populations. In Asia-Oceania there were 82 haplotypes; additional haplotypes found in Caucasoids were pooled to generate a $20 \times 83$ matrix for genetic distance calculations.

\section{Evidence from HLA Studies for Selection}

The mutation giving rise to DRBI 1408 in Polynesians is of functional significance in that it results in an amino acid change at position 57 in the DR beta molecule. The PCR-based protocol is capable of detecting silent mutations in hypervariable regions of the DRBl gene, and no novel silent mutations have been found in Polynesians. This suggests that the new functional mutation may have survived and flourished due to some selective advantage. Other evidence in favour of this hypothesis is that the same mutation has occurred in Australian Aborigines on a different DRB3 haplotype, suggesting independent mutations and convergent selection. The role of natural selection in shaping HLA-DR profiles is subject to debate (Hughes and Nei 1989), but it is possible that rare HLA types have been advantaged in epidemics.

\section{Evidence from HLA Studies for Migration Effects}

Phylogenetic analyses of HLA-DR,-DQ haplotype distributions in the populations listed in Table 1 and in Caucasoids (Fernandez-Viña et al. 1991) are given in Figures 1 and 2, based on Nei's distance statistic (Nei 1973). Figure 1 shows the extraordinary power of this small segment of the human genome, clustering populations in a manner partially expected from linguistic, anthropological and archaeological evidence (Bellwood 1989). The complete separation of Javanese 
and Polynesians, who show virtually no overlap in HLA-DR, DQ haplotypes (Gao and Serjeantson 1991a), is unexpected on linguistic grounds. The eigenvector (Figure 2) makes better use of the genetic data, representing genetic distance in two dimensions. Java is well-isolated from the other populations due to a near absence of DR4- and DRw6-related haplotypes; these haplotypes are well-represented in the other populations and account for the majority of HLA-DR types seen in Polynesia. The northern and southern Chinese populations cluster to the left of the eigenvector, while Xinjiang, a minority group with known Caucasoid ancestry, is positioned midway between Caucasoid and northern Chinese populations. The Polynesian groups have a position intermediate between northern China and coastal Melanesia. In the phylogenetic analysis, Melanesians from the north Papua New Guinea coast (Madang) cannot be discriminated from the Tolai of New Britain and these groups have a DR, DQ profile similar to that in Melanesians from New Caledonia. The Fijian sample reflects some admixture with Polynesian elements and is equidistant to New Caledonia and Western Samoa in the eigenvector diagram. Micronesians from Nauru and Kiribati are well-separated from Polynesians due to a high frequency of DRBI*1202, a DR5 allele that is commonly found in Javanese, less frequently in southern Chinese, and rarely elsewhere. Non-Austronesian-speaking Melanesians from the New Guinea Highlands show closer affinity with Australian Aborigines than with any of the Austronesian-speaking Melanesian groups. The Australian Aboriginal populations cluster together, even though about 50 per cent of HLA-DR alleles are unique to Kimberleys Aborigines. 
The Austronesians: Historical and Comparative Perspectives

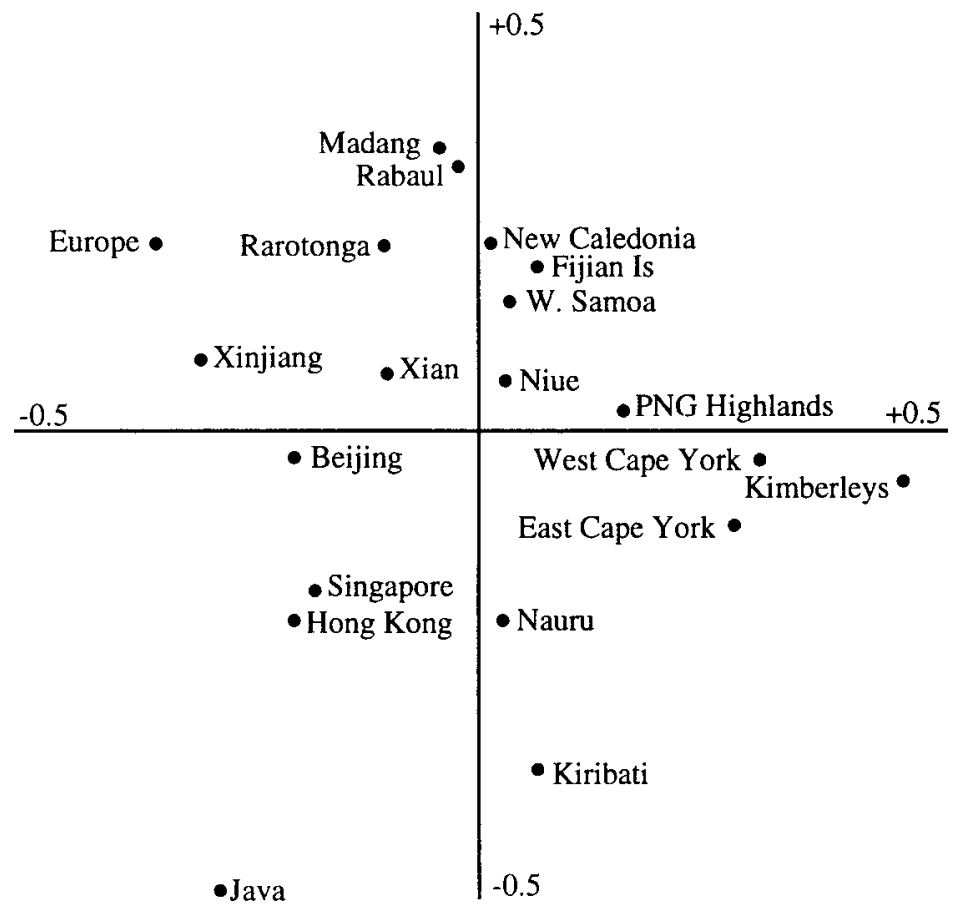

Figure 2. Eigenvector representation of genetic distances between 20 populations based on HLA-DR, DO haplotype frequency distributions.

This genetic distance analysis differs from that based on non-HLA markers (Kirk 1989) in that, in Kirk's study, Australian Aborigines showed closer affinities with Asian populations than with New Guinea Highlanders in the non-HLA analysis. However, we note that Kirk's Aboriginal sample was from central Australia whereas we have studied coastal people from Cape York and the Kimberleys; serological HLA profiles of central and northern Aboriginal populations are markedly different (Hay et al. 1986). This analysis based on HLA-DR, DQ haplotypes is more consistent with multivariate distances based on cranial measurements (Pietrusewsky 1984), in that Australian populations are well-separated from Austronesian-speaking groups and from Southeast Asia, and in that Java clusters with Southeast Asia rather than with Polynesia. The affinity between Fiji and Polynesia seen in the HLA-DR, DQ analyses was not seen by Pietrusewsky (1984) but was evident in the anthropometric analysis of Howells (1970).

\section{Comparative Observations From Other Genetic Systems}

Thus the combined forces of founder effect, genetic drift, migration and mutation have undoubtedly shaped the genetic profiles seen in contemporary Austronesian speakers. This conclusion based on HLA data is supported by studies of the distributions of the nine base-pair (bp) mitochondrial DNA deletion and of the 
$3.7 \mathrm{~kb}$ deletion in the $\alpha$ globin genes. The nine bp mitochondrial DNA deletion is another example of the role of chance in determining genetic profiles; since mtDNA is maternally-inherited, the number of copies in a colonizing group is equivalent to the number of females in that group. Thus we see the gradual loss of the wild-type or common non-deleted mtDNA as the early Austronesian-speakers moved through the Pacific. The deleted form has a frequency of 16 per cent in the Moluccas, 10-40 per cent in coastal Melanesia, 77 per cent in Tonga, 87 per cent in the Cook Islands, but reaches near fixation (frequency of 100 per cent) in Samoans and the New Zealand Maori (Hertzberg et al. 1989).

The common form of mtDNA was not the only genetic material lost to the pre-Polynesians as they moved eastwards through the Pacific. There are other examples of clines in gene frequencies from west to east, with final and irretrievable loss of the allele. At the HLA-B locus, for instance, HLA-B27 is not represented in eastern Polynesia, although this is a common antigen in island Melanesia (11 per cent in New Caledonia) and occurs in Mauke Island (6 per cent) (Serjeantson 1989). Similarly, HLA-B13 is found in western but not eastern Polynesia.

Another example of chance effects is the $3.7 \mathrm{~kb}$ deletion in the $\alpha$ globin genes $\left(\alpha^{-3.7}\right)$, which has a frequency of 15 per cent in Maoris. This deletion is clearly carried on a chromosome of Melanesian origin, because there are particular features in the DNA flanking the deletion (restriction enzyme sites) that are otherwise seen only in Melanesians. This has given rise to claims of substantial Melanesian genetic input into the contemporary Polynesian genome (Hill et al. 1989). However, the gene can be seen to increase in a cline from western to eastern Polynesia, increasing from 1 per cent in Tongans to 12 per cent in Cook Islanders to 15 per cent in Maoris (Hill et al. 1989). Thus the $\alpha^{-3.7}$ marker does not provide evidence that Polynesians evolved out of Melanesia; rather, it suggests that pre-Polynesians recruited at least one Melanesian into the mating pool.

It is clear that the recent PCR-based technological revolution in molecular genetics (Scharf et al. 1986), permitting rapid screening for the newly-sequenced alleles, will result in an explosion in knowledge of the genetic profiles of contemporary populations. PCR amplification of DNA from aged material has attracted much attention, but application of the PCR technique in reconstruction of genetic prehistory by analysis of contemporary populations is potentially very informative indeed.

How can the scholar of Austronesian prehistory best make use of the emerging PCR-based data? First, there will be an important role for the prehistorian who is prepared to examine the genetic tabulations and reinterpret them in language 
understood by his colleagues, wresting the data from the geneticists who with great abandon muddle geographic, anthropological and linguistic terms and muddle the reader (Houghton 1991)! Second, for the data to be relevant to archaeology they will need to be interpreted with due attention to the main thrust of this paper - that Homo sapiens is an evolving species. We conclude, from this small sample of the human genome, that founder effects, bottlenecks and mutations have resulted in a unique genetic profile in contemporary Polynesians, so that their origins are forever blurred. The Polynesian genetic repertoire at HLA-DR,DQ can largely be drawn from the East Asian gene pool, but has been irrevocably altered by evolutionary forces to generate the unique genetic repertoire that is distinctively Polynesian.

\section{Acknowledgements}

We thank many colleagues who have assisted us in the collection of, or who have collected, blood specimens: Michael Alpers, Kuldeep Bhatia, Max Blake, Gary Dowse, Brian Hawkins, Hilary King, R.L. Kirk, George Le Gonidec, Ken Mickleson, Ruby Newlands, Ray Pace, Salam Safro, Yiping Sun, Kiki Thoma, Ron Trent, A. Veale and Paul Zimmet.

\section{References}

Allen, J. and White, P.J.

1989 The Lapita homeland: some data and an interpretation. Journal of the Polynesian Society 98: 129-146.

Bellwood, P.

1989 The colonization of the Pacific: some current hypotheses. In: A.V.S. Hill and S.W. Serjeantson (eds) The colonization of the Pacific: a genetic trail, pp.1-59. Oxford: Clarendon Press.

Birky, C.W., P. Fuerst and T. Maruyama

1989 Organelle gene diversity under migration, mutation and drift: equilibrium expectations, approach to equilibrium, effects of heteroplasmic cells, DNA comparison to nuclear genes. Genetics 121:613-627.

Bodmer, J.G., S.G.E. Marsh, E. Albert et al.

1991 Nomenclature for factors of the HLA system, 1990. Tissue Antigens 37:97104.

Clark, J.T. and K.M. Kelly

1993 Human genetics, paleoenvironments, and malaria: relationships and implications for the settlement of Oceania. American Anthropologist 95(3): 612-630.

Fernandez-Viña, M., X. Gao, M.E.M. Moraes and P. Stastny 
1991 Alleles at four HLA class II loci and their associations determined by oligonucleotide hybridization in five different ethnic groups. Immunogenetics 34:299-312.

Gao, X. and S.W. Serjeantson

1991a Heterogeneity in HLA-DR2-related DR,DQ haplotypes in eight populations of Asia-Oceania. Immunogenetics 34:401-408.

1991b Diversity in HLA-DR4-related DR,DQ haplotypes in Australia, Oceania and China. Human Immunology 32:269-276.

Gao, X., P. Zimmet and S.W. Serjeantson

1992a HLA class II sequence polymorphisms in Pacific islanders. I. HLADR,DQ genes in Polynesians, Micronesians and Javanese. Human Immunology 34:151-161.

Gao, X., A. Veale and S.W. Serjeantson

1992b HLA class II diversity in Australian Aborigines: unusual HLA-DRB1 alleles. Immunogenetics 36:333-337.

Hay, J., G. Bennett, A. Sheldon and P. Hetzel

1986 Aboriginal Australians. In M. Aizawa et al. (eds) HLA in Asia-Oceania 1986, pp.295-297. Sapporo: Hokkaido University Press.

Hertzberg, M., K.N.P. Mickleson, S.W. Serjeantson, J.F. Prior and R.J. Trent

1989 An Asian-specific 9-bp deletion of mitochondrial DNA is frequently found in Polynesians. American Journal of Human Genetics 44:504-510.

Hill, A.V.S., D.F. O'Shaughnessy and J.B. Clegg

1989 Haemoglobin and globin gene variants in the Pacific. In A.V.S. Hill and S.W. Serjeantson (eds) The colonization of the Pacific: a genetic trail, pp.246-285. Oxford: Clarendon Press.

Houghton, P.

1991 The early human biology of the Pacific: some considerations. Journal of the Polynesian Society 100:167-196.

Howells, W.W.

1970 Anthropometric grouping analysis of Pacific peoples. Archaeology and Physical Anthropology in Oceania 5:192-217.

Hughes, A.L. and M. Nei

1989 Nucleotide substitution at major histocompatibility complex class II loci: Evidence for overdominant selection. Proceedings of the National Academy of Science U.S.A. 86:958-962.

Kelly, K.M. 
1992 On the genetic basis of hyperreactive malarious splenomegaly and the selection of G3m alleles. American Journal of Physical Anthropology Suppl. 14:98.

Kirk, R.L.

1989 Population genetic studies in the Pacific: red cell antigen, serum protein, and enzyme systems. In A.V.S. Hill and S.W. Serjeantson (eds) The colonization of the Pacific: a genetic trail, pp.60-119. Oxford: Clarendon Press.

Kohonen-Corish, M.R.J., H. Dunckley and S.W. Serjeantson

1988 HLA-DR and -DQ genotyping in seven populations of Asia-Oceania and Australia. Tissue Antigens 32:32-40.

Neel, J.

1968 The demography of two tribes of primitive relatively unaccultivated American Indians. Proceedings of the National Academy of Science U.S.A. 59:680-689.

Nei, M.

1973 The theory and estimation of genetic distance. In N.E. Norton (ed.) Genetic structure of populations, pp.45-51. Honolulu: University of Hawaii Press.

Pietrusewsky, M.

1984 Metric and non-metric cranial variation in Australian Aboriginal populations compared with populations from the Pacific and Asia. Occasional Papers in Human Biology, No. 3. Canberra: Australian Institute of Aboriginal Studies.

Scharf, S.J., G.T. Horn and H.A. Erlich

1986 Direct cloning and sequence analysis of enzymatically amplified genomic sequences. Science 233:1076-1078.

Serjeantson, S.W.

1989 HLA genes and antigens. In A.V.S. Hill and S.W. Serjeantson (eds) The colonization of the Pacific: a genetic trail, pp.120-173. Oxford: Clarendon Press.

Serjeantson, S.W., P.G. Board and K.K. Bhatia

1992 Population genetics in Papua New Guinea: a perspective on human evolution. In R.D. Attenborough and M.P. Alpers (eds) Human biology in Papua New Guinea: the small cosmos, pp.198-233. Oxford: Clarendon Press.

Serjeantson, S.W., R.L. Kirk and P.B. Booth 
1983 Linguistics and genetic differentiation in the Pacific. Journal of Human Evolution 12:77-92.

Serjeantson, S.W., D.P. Ryan, P. Zimmet, R. Taylor, R. Cross, M. Charpin and G. Le Gonidec

1982 HLA antigens in four Pacific populations with non-insulin-dependent diabetes mellitus. Annals of Human Biology 9:69-84.

Simmons, R.T.

1962 Blood groups and genes in Polynesians and comparisons with other Pacific peoples. Oceania 32:198-210.

Stoneking, M. and A.C. Wilson

1989 Mitochondrial DNA. In A.V.S. Hill and S.W. Serjeantson (eds) The colonization of the Pacific: a genetic trail, pp.215-245. Oxford: Clarendon Press. 